\title{
Abundance and distribution of Sardinella tawilis (Herre, 1927) larvae in Lake Taal, Philippines
}

\author{
Maria Theresa M. Mutia ${ }^{\star 1}$, Ma. Lourdes D. Merilles ${ }^{1}$, Myla C. Muyot ${ }^{1}$, Benjie D. Tordecilla ${ }^{1}$ \\ ${ }^{1}$ National Fisheries Research and Development Institute-National Fisheries Biological Center, Butong, \\ Taal, Batangas, Philippines
}

\begin{abstract}
A B S T R A C T
As part of the conservation efforts to address the declining population of the only freshwater Sardinella (Family Clupeidae) endemic to Lake Taal, a two-year study was conducted to determine the possible spawning grounds of Sardinella tawilis (Herre, 1927) by identifying the spatial and temporal distribution of its larvae. Fish larval samples were sorted from ichthyoplankton samples collected monthly in selected sampling stations in the lake. The morphologically identified Clupeidae larvae were determined to be S. tawilis genetically. They appeared only during March to May, with maximum abundance reaching from 700 to 1,700 ind $100 \mathrm{~m}^{-3}$ during April 2015. Among the 10 water, 5 weather, and 11 biological parameters analyzed using Redundancy Analysis (RDA), temperature and other weather parameters largely influenced the temporal distribution of tawilis larvae. In terms of spatial distribution, the stations on the eastern bay of the lake showed an abundant and consistent presence of tawilis larvae for two years. Other stations which showed the presence of tawilis larvae include the southern portion of the lake, as well as in stations south to southwest area of Volcano Island. The seasonal and site-specific occurrence of tawilis larvae confirmed its spawning season and potential spawning grounds, which can serve as a scientific basis in the establishment of a Tawilis Reserve Area, as stipulated in the Unified Rules and Regulations for Fisheries in the Taal Volcano Protected Landscape Management Plan (TVPL-MP 2011).
\end{abstract}

E-mail address: tmmutia@yahoo.com*

Received: August 15, 2018; Accepted: September 10, 2018
Keywords: Endemic, Sardine, Spawning ground, Clupeidae, Tawilis Reserve Area

\section{I N T R O D U C T I O N}

$S$ ardinella tawilis (Herre, 1927), locally known as tawilis (Family Clupeidae), is one of the most commercially important fish in the open fisheries of Lake Taal. It is the only freshwater species of the genus Sardinella and is endemic to Lake Taal, the third largest lake in the Philippines (Wongratana 1980; Whitehead 1985). It is mainly caught by gillnet, beach seine, and motorized push net (Mutia et al. 2004). The highest recorded production of tawilis was in 1984 with 29,000 MT (BFAR, as cited by Hargrove 1991 and Bleher 1996), and dramatically declined to 822 MT in 1994-95 (Villanueva et al. 1995) and five years later to 294 MT in 2000 (Mutia et al. 2004). Tawilis production has continuously declined since then. Exploitation rates (E) from 1994 to 2000 were estimated at 0.590.62 , indicating the stock is overfished (Villanueva et al. 1995; Mutia et al. 2004). Aside from unsustainable fishing practices, the introduction of non-native and invasive alien species are additional threats (Mutia et al. 2010).

In order to address the problem of declining tawilis catch and to revive its seemingly dwindling population, it is necessary to understand the biology of this endemic species. Biological studies conducted on S. tawilis (Castillo et al. 1975; Aypa et al. 1991; Villanueva et al. 1995; Mutia et al. 2004; Papa et al. 2008; Mutia et al. 2010; Papa and Zafaralla 2011; Magsino 2016) already covered feeding habits, length at first maturity, and stages of maturity, among others, but the actual spawning season and spawning grounds of tawilis in the lake remain to be poorly understood. In general, this study was conducted to determine the possible spawning grounds of $S$. tawilis in Lake Taal by analyzing patterns of its larval distribution. Specifically, the study aimed to determine the spatial and temporal distribution of S. tawilis larvae, to identify the relationship between the larval distribution of $S$. tawilis and selected environmental conditions, and 
to recommend policy options for sustainable development of tawilis fishery.

\section{MATERIALS AND METHODS}

\subsection{Study area}

Lake Taal is a tropical lake with volcanic origins located in the province of Batangas, Philippines. It is the country's third largest lake with an area of 24,236 hectares and one

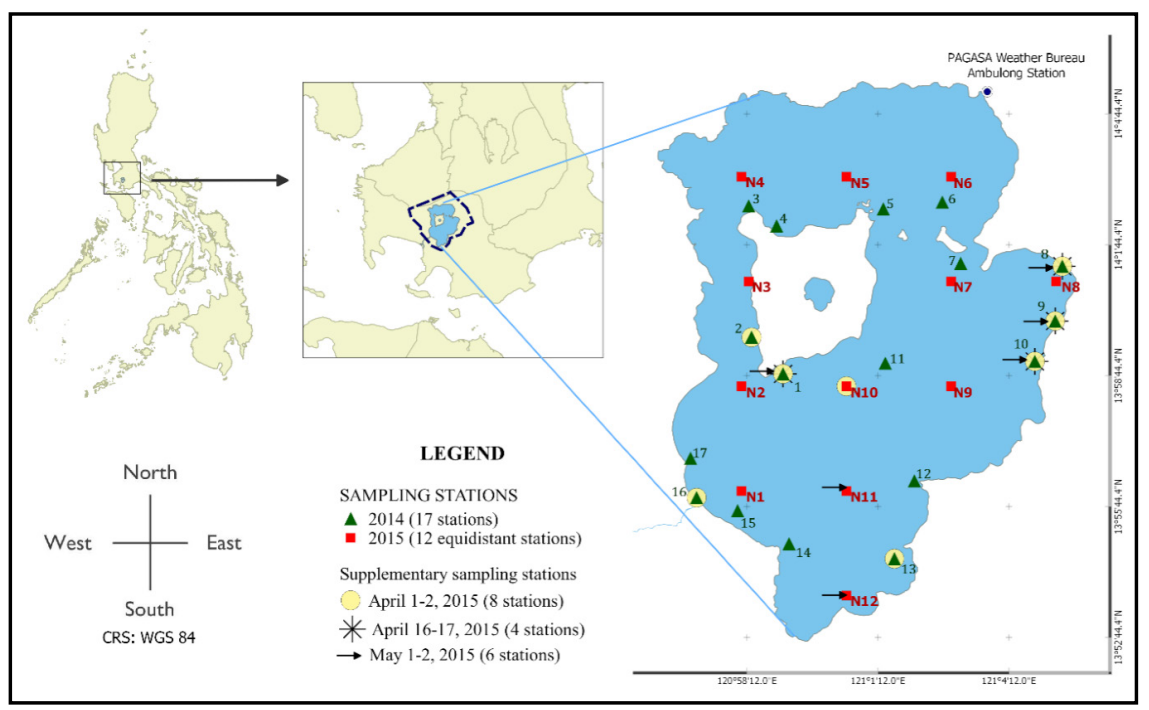

Figure 1. Map of location and sampling stations of Lake Taal, Philippines. of the deepest lakes with an average depth of 80 meters and a maximum depth of 198 meters (Castillo et al. 1975; Castillo and Gonzales 1976). The lake itself is divided into two basins: north and south basin (Perez et al. 2008). Nine municipalities (Talisay, Laurel, Agoncillo, San Nicolas, Sta. Teresita, Alitagtag, Cuenca, Mataasnakahoy, Balete) and two cities (Tanauan and Lipa City) surround the lake. The Lake Taal basin was declared as a protected area under Republic Act 7586 or the National Integrated Protected Areas System (NIPAS) Act of 1992 and named as Taal Volcano Protected Landscape (TVPL) by Proclamation 906 on October 16, 1996 (DENR 2011). The TVPL is managed by a Protected Area Management Board (PAMB) under the supervision of the Protected Area Superintendent (PASu). On September 26, 2009, the TVPL Management Plan was approved by PAMB and served as the blueprint for the lake conservation. Conservation measures to protect the population of the endemic species are outlined in Section 4B of the newly revised Unified Rules and Regulations on Fisheries of the Taal Volcano Protected Landscape (URRF-TVPL) Management Plan (DENR 2011).

\subsection{Sampling}

Monthly ichthyoplankton surveys were conducted for 24 months from January 2014 to December 2015. Sampling was done during nighttime, around $20: 00 \mathrm{H}$ to $07: 00 \mathrm{H}$ the following day. Figure 1 shows the geographic location of Lake Taal and the sampling stations. In 2014, sampling stations were selected based on the local knowledge of fisherfolk on tawilis fishing grounds. Seventeen stations (17) were sampled namely: (1) Pulang Bato, (2) Bird Sanctuary, (3) Binintiang Malaki, (4) Panikihan, (5) Pira-piraso, (6) Mahabang Buhangin, (7) Napayong, (8) Sala, (9) Kinalaglagan, (10) Nangkaan, (11) Puntor, (12) Napapanayan, (13) Don Juan, (14) Saimsim, (15) Tagudtod, (16) Pansipit, and (17) Subic.

In 2015, sampling stations were altered to determine the trends in spatial larval distribution. Twelve (12) equidistant (approximately $4.45 \mathrm{~km}$ in between) sampling stations scattered across the lake were sampled namely: N1, N2, N3, N4, N5, N6, N7, N8, N9, N10, N11, and N12. In addition, five sampling stations from 2014 were retained: Pulang Bato, Bird Sanctuary, Sala, Kinalaglagan, and Nangkaan. The sampling stations were georeferenced using a GPS receiver (Garmin GPS Map 76CSX), and coordinates were used as references during samplings. The coordinates for the 17 and 12 sampling stations are shown in Table 1.

Supplementary samplings were also conducted purposively on April 1-2, April 16-17, and May 1-2, 2015 on certain stations to validate the results generated from the same season of the previous year (2014) and to collect samples for genetic identification of tawilis larvae through DNA barcoding analysis. Stations sampled on April 1-2 were stations 1, 2, 8, $9,10,13,16$, and N10. Stations 1, 8, 9, and 10 were sampled on April 16-17 while stations sampled on May 1-2, 2015 included stations 1, 8, 9, 10, N11, and N12. Figure 1 shows the sampling stations in Lake Taal. 
The Philippine Journal of Fisheries 25(2): 16-26

Table 1. Sampling stations in Lake Taal with corresponding geographic coordinates.

\begin{tabular}{|c|c|c|c|c|c|}
\hline $\begin{array}{c}\text { Sampling } \\
\text { Station } \\
(2014)\end{array}$ & Latitude & Longitude & $\begin{array}{c}\text { Sampling } \\
\text { Station } \\
(2015)\end{array}$ & Latitude & Longitude \\
\hline 1 & $\mathrm{~N} 13^{\circ} 58^{\prime} 32.0^{\prime \prime}$ & E $120^{\circ} 58^{\prime} 39.7^{\prime \prime}$ & $\mathrm{N} 1$ & $\mathrm{~N} 13^{\circ} 56^{\prime} 06.4^{\prime \prime}$ & E $120^{\circ} 58^{\prime} 08.5^{\prime \prime}$ \\
\hline 2 & N $13^{\circ} 59^{\prime} 36.7^{\prime \prime}$ & E $120^{\circ} 58^{\prime} 20.1^{\prime \prime}$ & N2 & $\mathrm{N} 13^{\circ} 58^{\prime} 29.9^{\prime \prime}$ & E $120^{\circ} 58^{\prime} 02.5^{\prime \prime}$ \\
\hline 3 & $\mathrm{~N} 14^{\circ} 02^{\prime} 34.9^{\prime \prime}$ & E $120^{\circ} 58^{\prime} 11.8^{\prime \prime}$ & N3 & $\mathrm{N} 14^{\circ} 01^{\prime} 00.2^{\prime \prime}$ & E $120^{\circ} 58^{\prime} 11.4^{\prime \prime}$ \\
\hline 4 & $\mathrm{~N} \mathrm{14} 4^{\circ} 02^{\prime} 10.7^{\prime \prime}$ & E $120^{\circ} 58^{\prime} 52.8^{\prime \prime}$ & $\mathrm{N} 4$ & $\mathrm{~N} 14^{\circ} 03^{\prime} 21.3^{\prime \prime}$ & E $120^{\circ} 58^{\prime} 05.7^{\prime \prime}$ \\
\hline 5 & 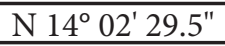 & E $121^{\circ} 01^{\prime} 31.5^{\prime \prime}$ & N5 & $\mathrm{N} 14^{\circ} 03^{\prime} 19.0^{\prime \prime}$ & E $121^{\circ} 00^{\prime} 30.8^{\prime \prime}$ \\
\hline 6 & N 14º $02^{\prime} 18.4^{\prime \prime}$ & E $121^{\circ} 02^{\prime} 57.4^{\prime \prime}$ & N6 & $\mathrm{N} 14^{\circ} 03^{\prime} 18.7^{\prime \prime}$ & E $121^{\circ} 02^{\prime} 53.8^{\prime \prime}$ \\
\hline 7 & N 14 $01^{\circ} 15.6^{\prime \prime}$ & E $121^{\circ} 03^{\prime} 04.5^{\prime \prime}$ & N7 & $\mathrm{N} 14^{\circ} 00^{\prime} 52.2^{\prime \prime}$ & E $121^{\circ} 02^{\prime} 53.2^{\prime \prime}$ \\
\hline 8 & $\mathrm{~N} \mathrm{14^{ \circ } 0 1 ^ { \prime } 1 2 . 5 ^ { \prime \prime }}$ & E $121^{\circ} 05^{\prime} 28.1^{\prime \prime}$ & $\mathrm{N} 8$ & $\mathrm{~N} 14^{\circ} 00^{\prime} 53.3^{\prime \prime}$ & E $121^{\circ} 05^{\prime} 16.7^{\prime \prime}$ \\
\hline 9 & N 13 $59^{\prime} 55.8^{\prime \prime}$ & E $121^{\circ} 05^{\prime} 12.1^{\prime \prime}$ & N9 & $\mathrm{N} 13^{\circ} 58^{\prime} 28.3^{\prime \prime}$ & $\mathrm{E} 121^{\circ} 02^{\prime} 50.8^{\prime \prime}$ \\
\hline 10 & $\mathrm{~N} 13^{\circ} 59^{\prime} 36.3^{\prime \prime}$ & E $121^{\circ} 05^{\prime} 00.3^{\prime \prime}$ & N10 & $\mathrm{N} 13^{\circ} 58^{\prime} 30.2^{\prime \prime}$ & $\mathrm{E} 121^{\circ} 00^{\prime} 28.9^{\prime \prime}$ \\
\hline 11 & N $13^{\circ} 59^{\prime} 01.7^{\prime \prime}$ & E $121^{\circ} 01^{\prime} 22.1^{\prime \prime}$ & N11 & $\mathrm{N} 13^{\circ} 56^{\prime} 00.4^{\prime \prime}$ & E $121^{\circ} 00^{\prime} 28.9^{\prime \prime}$ \\
\hline 12 & $\mathrm{~N} 13^{\circ} 56^{\prime} 19.8^{\prime \prime}$ & E $121^{\circ} 02^{\prime} 02.2^{\prime \prime}$ & N12 & $\mathrm{N} 13^{\circ} 53^{\prime} 40.8^{\prime \prime}$ & $\mathrm{E} 121^{\circ} 00^{\prime} 28.9^{\prime \prime}$ \\
\hline 13 & N $13^{\circ} 54^{\prime} 32.8^{\prime \prime}$ & E $121^{\circ} 01^{\prime} 34.8^{\prime \prime}$ & & & \\
\hline 14 & 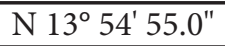 & E $120^{\circ} 59^{\prime} 04.4^{\prime \prime}$ & & & \\
\hline 15 & $\mathrm{~N} 13^{\circ} 55^{\prime} 37.0^{\prime \prime}$ & E $120^{\circ} 58^{\prime} 01.5^{\prime \prime}$ & & & \\
\hline 16 & $\mathrm{~N} 13^{\circ} 55^{\prime} 58.5^{\prime \prime}$ & E $120^{\circ} 56^{\prime} 59.7^{\prime \prime}$ & & & \\
\hline 17 & $\mathrm{~N} \mathrm{13} 3^{\circ} 56^{\prime} 51.0^{\prime \prime}$ & E $120^{\circ} 56^{\prime} 53.2^{\prime \prime}$ & & & \\
\hline
\end{tabular}

\subsection{Sample and Data Collection}

2.3.1. Ichthyoplankton. Samples were collected using a plankton net $(330 \mu \mathrm{m}$ mesh size; $0.5 \mathrm{~m}$ diameter \& 2m length) gauged with a Model 2030R standard flowmeter. Horizontal tows were obtained by means of 10-minute (sub-surface; within upper $1 \mathrm{~m}$ ) tows at an average speed of 1.5 knots (Smith and Richardson 1977). The samples collected from the plankton net were immediately preserved with ethanol (70\% final solution). Further processing of the ichthyoplankton samples was done in the laboratory.

2.3.2. Phytoplankton. Using a $20 \mu \mathrm{m}$ mesh phytoplankton net (30 $\mathrm{cm}$ diameter; $1 \mathrm{~m}$ length), samples were collected by vertically towing the net to a depth of 5 meters below the surface. The collected samples were placed in a vial and fixed with Lugol's iodine (APHA 1998).

2.3.3. Zooplankton. Samples were collected by vertical tows (20m below the surface) using a $64 \mu \mathrm{m}$ mesh plankton net $(30 \mathrm{~cm}$ diameter; $1 \mathrm{~m}$ length). The samples were placed in a vial and preserved with $10 \%$ formalin (APHA 1998).

2.3.4. Water quality and nutrients. During plankton tows in each station, water parameters (water temperature, conductivity, total dissolved solids, salinity, dissolved oxygen, $\mathrm{pH}$, turbidity, and chlorophyll) were measured using a YSI 6600 V2 Multiparameter Water Quality Sonde. In addition, water samples were collected in the subsurface using a 1000-ml sampling water bottle. The samples were brought to the laboratory and analyzed immediately for ammonia, nitrite, nitrate, and phosphate using LaMotte SMART3 Colorimeter. Alkalinity and hardness were analyzed using $\mathrm{HACH}$ Test Kit. Records of in situ measurement of water parameters were uploaded from the YSI Sonde to PC and transformed into average readings per month.

2.3.5. Meteorological data. Secondary meteorological data were obtained from the Weather Bureau, Ambulong Station of the Philippine Atmospheric, Geophysical, and Astronomic Services Administration (Figure 1). Secondary data obtained include daily readings of air temperature, relative humidity, rainfall, wind speed, wind direction and cloudiness from January 2014 to December 2015.

\subsection{Sample Processing and Data Analysis}

In the laboratory, ichthyoplankton samples were immediately sorted for fish larvae following Smith and Richardson's (1977) standard procedure for zooplankton biomass measurement and sorting 
using a dissecting microscope, Olympus SZ51. The sorted fish larvae were morphologically identified up to Family level using key identification guides (Moser 1996; Leis and Carson-Ewart 2000; Richards 2005). Using a compound microscope with an ocular micrometer, morphological characteristics such as body length (BL), body depth (BD), and pre-anal length (PAL) were measured. Since $S$. tawilis is the only member of Family Clupeidae in the Lake Taal, larvae with morphological characteristics similar to that of Family Clupeidae (Bensam 1987; Ditty et al. 1994; Watson and Sandknop 1996; Ditty et al. 2006) were identified as $S$. tawilis larvae.

Using samples obtained from the supplementary samplings, the morphologically preidentified tawilis larvae samples were submitted to the National Fisheries Research and Development Institute-Genetic Fingerprinting Laboratory (NFRDIGFL) for validation of identification through DNA Barcoding analysis. The submitted larval samples preserved in $70 \%$ ethyl alcohol were photographed and subjected wholly for DNA extraction. Identification of $S$. tawilis larvae was confirmed through the utilization of the DNA barcode marker cytochrome c oxidase I (COI) gene and the Kimura 2-parameter (K2P) distance model. Detailed methodology in the genetic identification of S. tawilis larvae is described in Mutia et al. (2017).

The number of fish larvae was translated into density (ind $100 \mathrm{~m}^{-3}$ ) using the standard procedure in the Larval Fish Identification Guide by the Southeast Asian Fisheries Development Center (SEAFDEC). The volume of water filtered in every tow was determined using the formula derived from the flowmeter's manual.

$$
\mathrm{V}=\pi r^{2}\left(\frac{\left(F M_{f}-F M i\right) \times R C}{999999}\right)
$$

where:

$\mathrm{V}=$ volume of water filtered

$\mathrm{r}=$ radius of plankton net

$\mathrm{FMf}=$ final flow meter reading

$\mathrm{FMi}=$ initial flow meter reading

$\mathrm{RC}=$ rotor constant

Phytoplankton and zooplankton samples were microscopically examined under a compound microscope. The species were identified morphologically in the lowest taxa possible using Zafaralla (1998) for phytoplankton, and Mamaril Sr. and Fernando (1978) and Papa and Zafaralla (2011) for zooplankton. Quantification of different groups of plankton was determined using a Neubauer-type Haemacytometer for phytoplankton and SedgewickRafter Counting Chamber for zooplankton. The counts were translated into density (units L-1 for phytoplankton and individuals L-1 for zooplankton) using the formula:

$$
D\left(\frac{\text { individuals }}{\mathrm{L}}\right)=\frac{N \cdot V_{1}}{V_{2}}
$$

Where:

$\mathrm{N}=$ number of individuals in $1 \mathrm{ml}$ sample

$\mathrm{V}_{1}=$ total volume of the plankton sample $(\mathrm{ml})$

$\mathrm{V}_{2}=$ volume of the lakewater filtered by plankton net within hauling depth $(\mathrm{ml})$

A Geographic Information System (GIS Chiugak 2.4.0) was used to produce distribution maps of tawilis larvae in terms of abundance (density) across the lake. The effects of environmental variables on tawilis larvae and other biological parameters were analyzed using the software CANOCO (version 5.0) for Windows. Since DCA ordination showed the compositional length of the environmental gradient to be 0.5 SD units long, Redundancy Analysis (RDA) was employed. Data were pooled by months on the basis of abundance values. Larval abundances were logarithmically transformed $[\log (y+1)]$, and the environmental variables were square-roottransformed prior to ordination analyses. Results were illustrated with a tri-plot (Type II scaling-response variable focused): tawilis larvae and all other plankton vs water/weather parameters.

\section{RES ULT S}

In terms of density, an overall mean of 123.38 ind $100 \mathrm{~m}^{-3}$ fish larvae were collected within the duration of the study. Of these, only $1.41 \%$ were morphologically identified as Family Clupeidae. DNA barcoding analysis of samples morphologically identified as Clupeid larvae revealed a positive identification to Sardinella tawilis (Mutia et al. 2017). In 2014 , only $0.12 \%$ of the overall larvae were S. tawilis while in 2015 the percentage increased to $2.66 \%$. Most of the larvae identified belonged to Families Atherinidae, Blenniidae, Gobiidae, and Syngnathidae, among others. Figure 2 shows that the overall larval density varied across months. In both years, 
Table 2. Monthly means of overall and Clupeidae larval densities (ind $100 \mathrm{~m}^{-3}$ ) across stations.

\begin{tabular}{|c|c|c|c|c|}
\hline Year & Sampling & $\begin{array}{c}\text { No. of } \\
\text { stations }\end{array}$ & $\begin{array}{c}\text { Mean Larval Density } \\
\pm \mathrm{SD}\end{array}$ & $\begin{array}{c}\text { Mean Clupeidae Density } \\
\text { (Range) }\end{array}$ \\
\hline 2014 & January 28-29 & 17 & $7.48 \pm 4.34$ & 0.00 \\
\hline & February 26-27 & 17 & $526.25 \pm 172.16$ & 0.00 \\
\hline & March 25-26 & 17 & $425.66 \pm 71.14$ & $1.28 \quad(0.00-11.61)$ \\
\hline & April 22-23 & 17 & $255.00 \pm 59.59$ & $0.99 \quad(0.00-7.06)$ \\
\hline & May 7-8 & 17 & $145.88 \pm 29.20$ & 0.00 \\
\hline & June 27-28 & 17 & $17.65 \pm 9.99$ & 0.00 \\
\hline & July $26-27$ & 17 & $43.39 \pm 16.06$ & 0.00 \\
\hline & August $19-20$ & 17 & $21.15 \pm 9.21$ & 0.00 \\
\hline & September 24-25 & 17 & $32.90 \pm 9.70$ & 0.00 \\
\hline & October 23-24 & 17 & $260.14 \pm 138.38$ & 0.00 \\
\hline & November 24-25 & 17 & $58.96 \pm 19.77$ & 0.00 \\
\hline & December 16-17 & 17 & $81.83 \pm 31.39$ & 0.00 \\
\hline 2015 & January 22-23 & 12 & $132.51 \pm 44.55$ & 0.00 \\
\hline & February 18-19 & 9 & $279.51 \pm 58.70$ & 0.00 \\
\hline & March 18-19 & 17 & $104.46 \pm 32.66$ & $3.13 \quad(0.00-84.23)$ \\
\hline & April 1-2* & 8 & $329.70 \pm 100.44$ & $112.24 \quad(0.00-550.15)$ \\
\hline & April 16-17* & 4 & $54.63 \pm 32.13$ & 0.00 \\
\hline & April 28-29 & 17 & $78.79 \pm 20.26$ & $22.87 \quad(0.00-259.07)$ \\
\hline & May $1-2^{*}$ & 6 & $82.47 \pm 68.86$ & 0.00 \\
\hline & May 15-16 & 17 & $24.11 \pm 9.36$ & $0.07 \quad(0.00-2.34)$ \\
\hline & June 16-17 & 17 & $6.22 \pm 3.64$ & 0.00 \\
\hline & July $25-26$ & 16 & $73.27 \pm 30.56$ & 0.00 \\
\hline & August 25-26 & 17 & $47.26 \pm 29.30$ & 0.00 \\
\hline & September 24-25 & 17 & $13.81 \pm 6.10$ & 0.00 \\
\hline & October 22-23 & 17 & $137.46 \pm 43.02$ & 0.00 \\
\hline & November $19-20$ & 17 & $91.18 \pm 27.97$ & 0.00 \\
\hline & December 9-10 & 17 & $96.18 \pm 35.61$ & 0.00 \\
\hline \multicolumn{3}{|c|}{ OVERALL MEAN } & $123.38 \pm 38.03$ & \\
\hline
\end{tabular}

*supplementary samplings

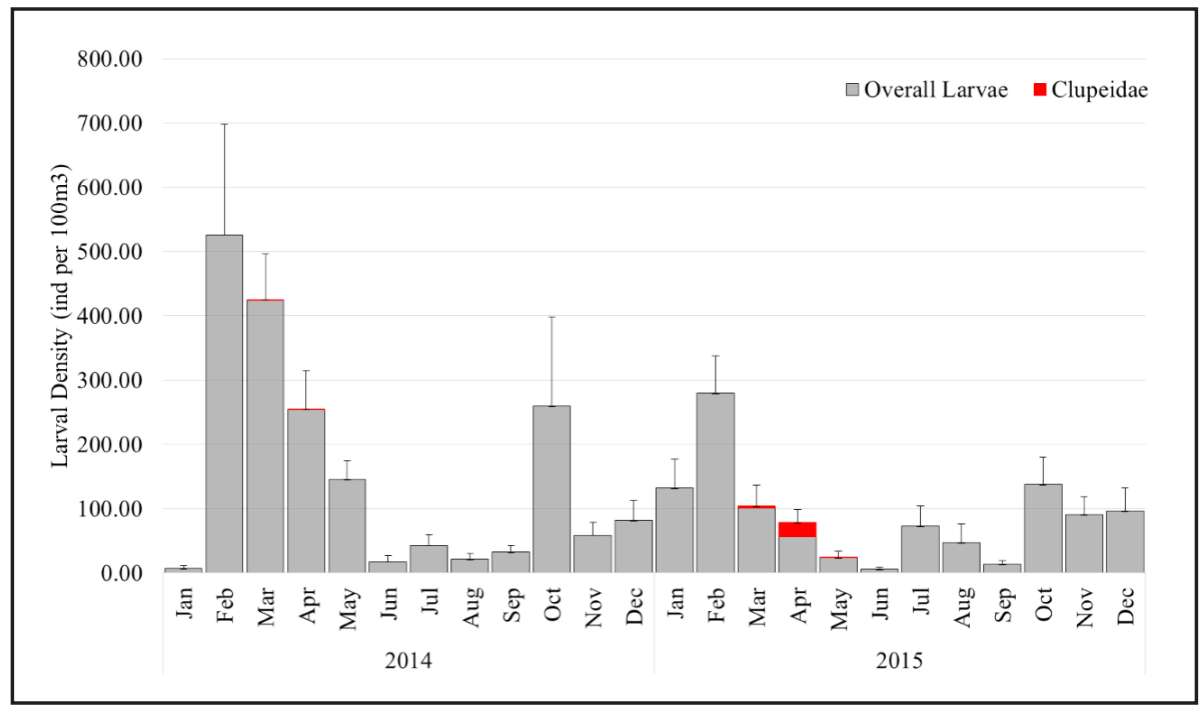

Figure 2. Overall abundance of fish larvae collected in Lake Taal (red bar: S. tawilis larval abundance) from January 2014 to December 2015. 
larval density was highest in February. Across the sampling period, S. tawilis larvae appeared only in March and April of 2014 and from March to May of 2015.

$$
\text { All stations }
$$

sampled showed a presence of larvae, however, larvae of S. tawilis only appeared in selected stations. A total of 240 larval samples of S. tawilis were collected within the study period. In 2014, mean densities of 1.28 and 0.99 ind $100 \mathrm{~m}^{-3}$ were collected during March and April, respectively (Table 2). In 2015 , mean densities ranged from 0.07 to 112.24 ind $100 \mathrm{~m}^{-3}$. Actual densities of tawilis larvae collected in certain stations ranged from 2.34 to 550.15 ind $100 \mathrm{~m}^{-3}$. In terms of spatial distribution, tawilis larvae were collected in three out of 17 stations $(8,9$, and 10$)$ in March 2014 and four out of 17 stations $(1,9,10$, and 13$)$ in April 2014. In 2015, tawilis larvae were collected in two out of 17 stations in March

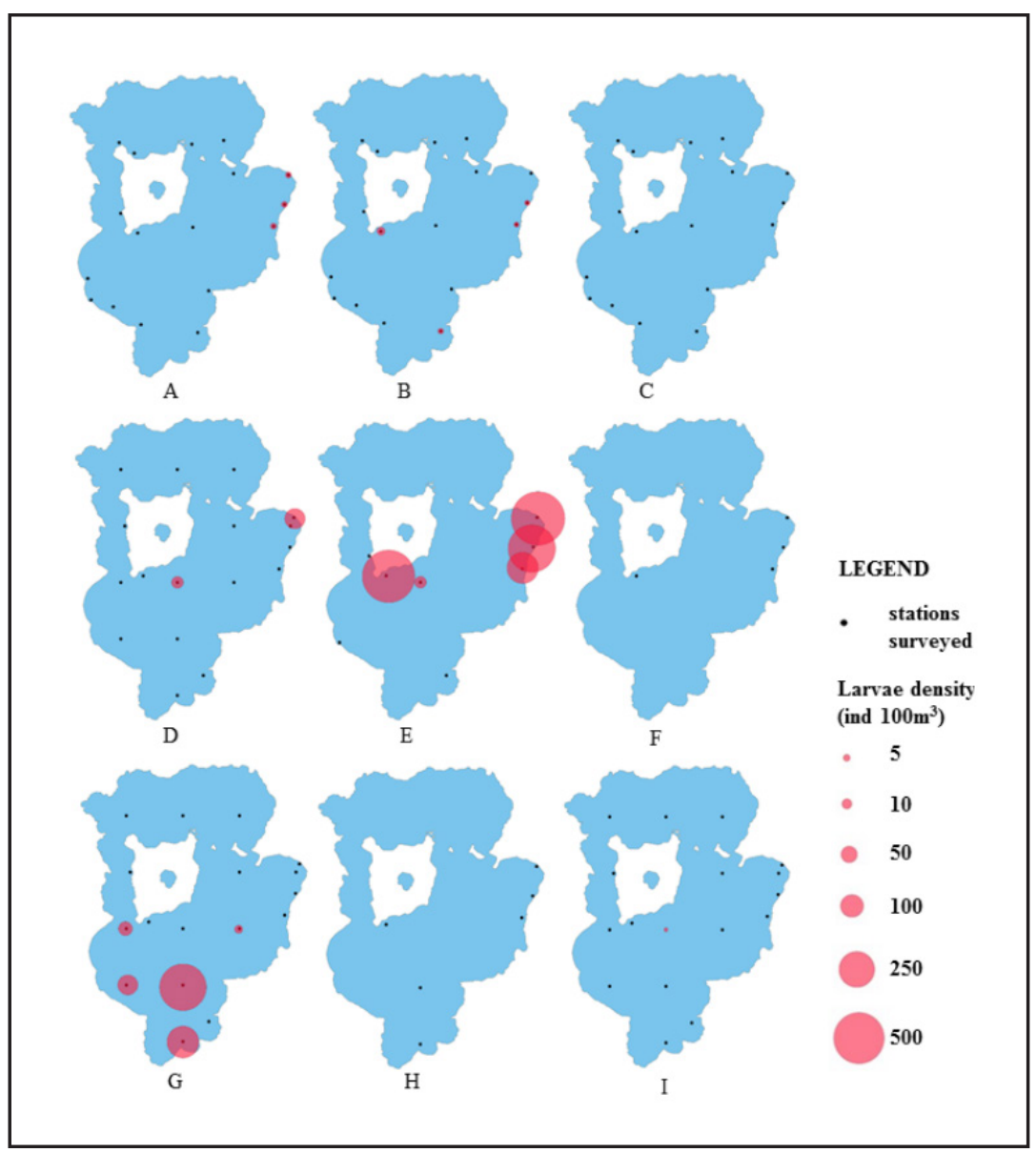

Figure 3. Spatial distribution maps of abundance of S. tawilis larvae on the following surveys: (A) March 25-26, 2014; (B) April 22-23, 2014; (C) May 7-8, 2014; (D) March 18-19, 2015;

(E) April 1-2, 2015; (F) April 16-17, 2015; (G) April 28-29, 2015; (H) May 1-2, 2015; (I) May 15-16, 2015. Red circles are size-scaled abundance of $S$. tawilis larvae.
(8, and N10), five out of

eight stations on April 1-2 (1, 8, 9, 10, and N10), five out of 17 stations on April 28-29 (N1, N2, N9, N11, and N12), and one out of 17 stations on May 15-16 (N10). The highest mean density was recorded during supplementary sampling on 1-2 April 2015, while only two individuals of tawilis larvae were spotted during May 2015 in station N10. No tawilis larvae were collected in-between samplings of April and May, i.e. during April 16-17 and May 1-2, 2015.

To illustrate, Figure 3 shows the spatial and temporal distribution of the identified tawilis larvae in the lake. The abundance (in terms of density) is represented by size-scaled circles (see legend). In 2014, tawilis larvae were observed in stations along the eastern portion of the lake, at the southwest of the Volcano Island, and in one station along the southern bay. In 2015, all equidistant stations on the southern basin (N1, N2, N9, N10, N11, and N12) were observed with tawilis larvae. Supplementary sampling also showed presence and abundance of tawilis larvae along the eastern portion of the lake as well as in other stations previously observed with tawilis in 2014. The morphological measurements and ontogenetic stages of each larvae sample were determined irrespective of the collection station. Nevertheless, most of the larvae collected per survey from March 2014 to May 2015 were in the pre-flexion stage ( $>50 \%$ per survey), with a mean $\mathrm{BL}$ of $3.87 \pm \mathrm{mm}$.

The temporal trends in selected environmental factors (water temperature, conductivity, total dissolved solids, salinity, dissolved oxygen, $\mathrm{pH}$, turbidity, chlorophyll, air temperature, relative humidity, rainfall, wind speed, wind direction, cloudiness) were used to analyze the abundance of tawilis larvae and other biological factors (abundances of different groups of phytoplankton and zooplankton) 


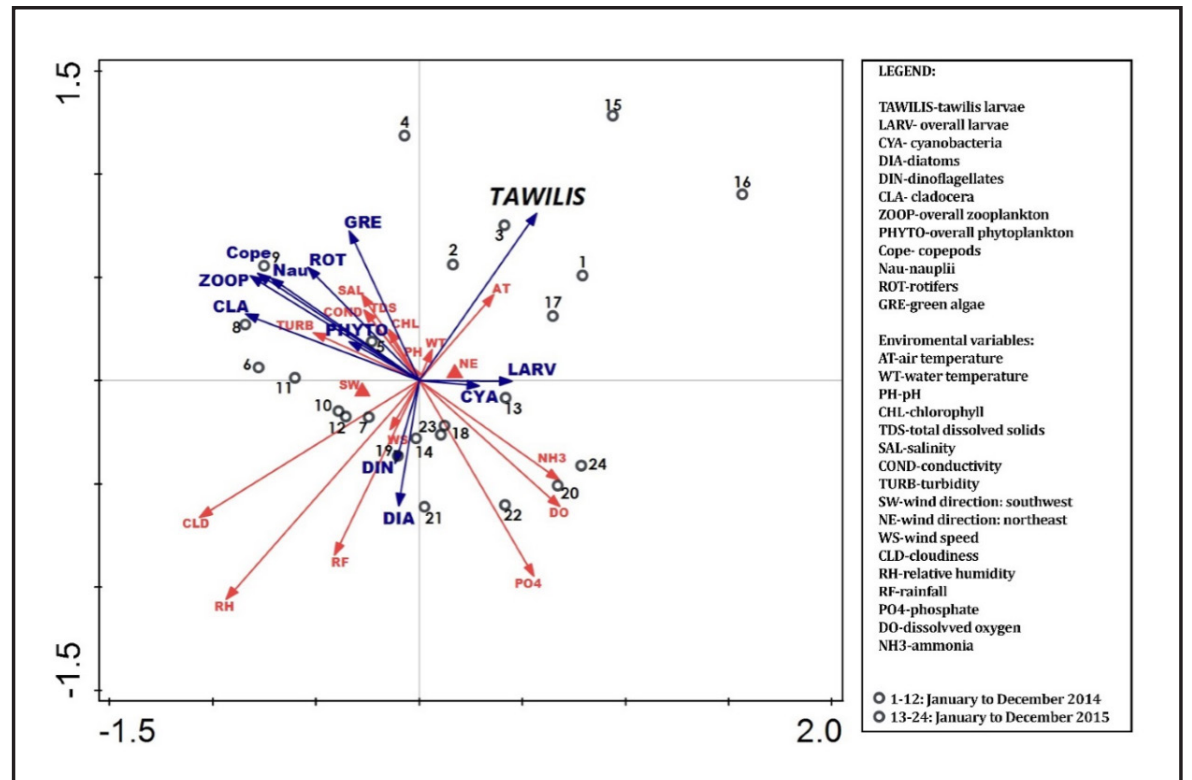

Figure 4. Redundancy analysis tri-plot of monthly (dots) temporal variations in tawilis larval composition and other biological parameters (indicated by solid blue arrows) and environmental variables (indicated by red arrows).

using Redundancy Analysis. The RDA model (Figure 4) revealed the relationships between larvae monthly occurrence patterns and environmental variables. The combined effect of the first two canonical axes explains $61.32 \%$ of the total variance of data. An overall test of significance showed that the relationship between the environmental parameters and tawilis larval abundances is not significant $(\mathrm{p}>0.05)$. The tri-plot (Figure 4) shows little correlation of tawilis larvae with most of the water and biological parameters. However, the negative effects of parameters such as cloudiness, rainfall, and relative humidity imply that the lowest values of these variables (which likely occur during the dry months) were timed together with high tawilis abundance. As for plankton, there are obvious seasons for different groups of phytoplankton while zooplankton groups are clumped with turbidity, conductivity, salinity, TDS, and $\mathrm{pH}$ water parameters.

\section{D I S C U S S I O N}

Sardines are known broadcast (multiple batches) spawners (Lasker 1985), i.e., they shed their eggs and sperm into the water column, thus their spawning grounds can be characterized by the presence of eggs and larvae (Somarakis et al. 2006; Ellis et al. 2012). However, fish eggs are difficult to identify, hence identification of potential spawning grounds of tawilis relied on the distribution of larvae morphologically identified as Family Clupeidae, which was later genetically identified as $S$. tawilis (Mutia et al. 2017). Being the only representative species of Family Clupeidae in the freshwater Lake Taal, the morphology of tawilis larvae is fairly different from the larvae of any other known fish in the lake. Clupeid larvae have a very elongated body shape and a long gut. Its pre-anal length extends to about $70 \%$ of its body length. In marine ecosystems, the spatial and temporal distribution of ichthyoplankton comprised abundantly of Clupeid larvae among other families (Sarpedonti et al. 2013). In the freshwater Lake Taal, most of the fish larvae identified belonged to other families such as Blenniidae, Gobiidae, Atherinidae, Ambassidae, and Syngnathidae.

The tawilis larvae were seasonal, observed only during the months of March, April, and May for both years, 2014 and 2015. The seasonality of S. tawilis larvae suggests that there is a high probability of collecting S. tawilis larvae from March to May-an indication that these months are the species' major spawning season. While some reports of spawning season of tawilis seem contradictory, there are instances when they overlap. In 1975, the spawning season of $S$. tawilis was reported twice a year, recurrently during February-April and intermittently during AugustNovember (Castillo et al. 1975). In contrast, Aypa et al. (1991) reported the peak spawning months of tawilis were from May to July based on the greater 
number of gravid individuals during this season with a possible intermittent spawning during SeptemberOctober and February-March. Another study reports February-April as the spawning period of tawilis based on the gonadosomatic index (Catedral 2002) while the latest study on the reproductive biology of tawilis states that peak spawning occurs during March-April (Mutia 2015). The more recent studies seem to agree that peak spawning occurs during March-April, which is further validated by the presence of tawilis larvae in March and April of 2014 and 2015. As suggested by the RDA analysis results, the months of March and April are also when the temperature (air and water temperatures) begin to increase as well as when the prevailing wind direction changes from northeast to southwest. In temperate and cold oceans, temperature is known as the principal factor controlling the spatiotemporal occurrence of fish eggs and larvae (Blaxter 1991; Doyle et al. 1993; Laprise \& Pepin 1995). Still, the possibility of collecting tawilis larvae during the reported intermittent spawning seasons is not discounted, except that during intermittent months larvae may be more dispersed, or that the spawning duration is short and restricted for monthly sampling to cover. In this case, it may be more appropriate to conduct a study with a finer grid of stations and/or more frequent surveys to cover the precise season or spawning dynamics of $S$. tawilis.

The supplementary sampling conducted in April 2015 validated the 2014 stations observed with tawilis larvae. Stations near the coastlines of Balete and Mataasnakahoy (eastern bay of the lake) showed a consistent presence of tawilis larvae during MarchApril of 2014 and 2015 (Figure 3A, 3B, 3D, and 3E). In addition, the station near the coast of Balete recorded the highest larval abundance. This nearshore area is characterized by shallow waters, with an average depth of ten meters and lush growth of aquatic macrophytes locally referred to as isayan. Interestingly, no manifestation of tawilis larvae occurred in these stations during April 16-17 and 28-29, 2015 surveys (Figure $3 \mathrm{~F}$ and $3 \mathrm{G}$ ). There are about a $14-$ and a $27-$ day interval between the three surveys. Tawilis larvae collected on April 1-2 and 28-29 appeared in entirely different stations. Either the two surveys reflected larvae from separate spawning events or there is a transport of larvae from the east bay to the south basin of the lake within the interval period. The hydrography of the lake has not yet been studied and needs to be examined to make more sound inferences about larval transport within the lake. However, in the absence of such knowledge, information on the prevailing winds may be useful. The prevailing wind direction during this month was the NE monsoon (PAGASA), which could have influenced larval transport from the eastern bay towards the southwest of the lake. However, the larvae of the April 28-29, 2015 survey consisted mostly of the pre-flexion stage $(>75 \%)$. Considering that larval development from pre-flexion to post-flexion occurs around 40 days post hatch (dph) (Silva et al. 2014), the two surveys are more likely to be separate spawning events in different locations. The southwest coastline of Volcano Island also showed a consistent presence of tawilis larvae (Figure 3B, 3D, 3E, 3G). There was no yolk-sac stage of tawilis larvae collected within the duration of study but the high percentage of pre-flexion stage and abundance of tawilis larvae on April 1-2 and 28-29, 2015 surveys (>80\%) suggest that tawilis' spawning occurs in particular areas in the lake.

The prolonged period of wind mixing of the water column due to NE monsoon in the lake (Perez et al. 2008) could have also influenced the vertical distribution of tawilis larvae. Sardine larvae are reported to exhibit vertical movement/migration patterns which are difficult to characterize (GarcíaGarcía et al. 2016) because of the influence of several factors, such as light and food availability and local conditions (Olivar et al. 2001; Sabates \& Sabatés 1990). However, these factors were not explored in this study with regards to its vertical distribution. Considering the absence of yolk sac stages, the collected larval samples are already capable of exogenous feeding. Sardine larvae mostly feed on zooplankton, specifically copepod stages (Munuera-Fernandez and GonzalezQuiros 2006; Voss et al. 2009; Morote et al. 2010) but the low correlation values between tawilis larvae and its prey items such as zooplankton (overall and copepod), phytoplankton, and chlorophyll levels suggest other environmental factors determine larval distribution. In literature, there is a substantial vertical movement of sardine larvae within the top 20-30 m (Santos et al. 2006; Sabates, 2004), which is far greater than the layer surveyed in this study $(0-1 \mathrm{~m})$. The likelihood of missed larval concentrations at slightly deeper layers in stations with low or absence of tawilis larvae is possible. As spawning is generally limited to specific areas and times (Cushing 1990), the recurrence and abundance of $S$. tawilis larvae in certain areas (the eastern bay of the lake, the southwest coast of Volcano Island, and the open water in the southern basin) in separate surveys, even in low abundances and only at 0-1 m water depth, increase the probability of these areas as spawning grounds of $S$. tawilis. Hence, these areas should be considered part of the Tawilis Reserve 
Areas for protective management, particularly during the peak spawning months.

\section{C O N C L US I O N}

The present study investigated larval distribution patterns of tawilis from 2014 to 2015. Ichthyoplankton sampling and biophysico-chemical parameters monitoring were conducted monthly to determine the spatial and temporal distribution of tawilis larvae and to determine the factors associated with its distribution. Ichthyoplankton sampling across the lake revealed seasonality in collecting tawilis larvae from March to April. However, no significance was noted among all the physicochemical parameters except for the parameters of which the negative effects are associated with summer months (cloudiness, relative humidity, and rainfall) were timed with months of abundant S. tawilis larvae. Spatial distribution of tawilis larvae within the upper one-meter of the water column is limited to the southern basin, especially on the eastern bay of the lake, as well as areas on the southwestern portion of the Volcano Island and on the open waters of the southern basin. The spawning dynamics of $S$. tawilis remains to be understood including spatial variability and vertical distribution along the water column. Nevertheless, the spatial and temporal distribution patterns of tawilis larvae can be used as a preliminary basis for identifying tawilis spawning grounds and establishment of Tawilis Reserve Areas for the conservation and protection of this endemic species.

\section{A C K N O W L D G M E N T}

The authors would like to acknowledge the National Fisheries Research and Development Institute (NFRDI) for financial support. Special thanks are also given to Dr. Mudjekeewis Santos and Katreena P. Sarmiento for genetically identifying tawilis larvae samples. The authors are also indebted to the Lake Taal towing/support team, namely, Charice M. Faminialagao, Mae Anne P. Gardon, Arnolfo C. Atienza, Jessel Y. Tuazon, Gemma Corral, Maria Teresa M. Alcazar, Alexis P. Martinez, Arwin S. Alcazar, and especially to our boatmen, Michael de Sagun, Oscar de Sagun, and Manuel Matienzo.

\section{R E F E R E N C E S}

APHA. 1998. Standard methods for examination of water and wastewater. 20th ed. Washington, DC:
American Public Health Association, Inc.

Aypa S, Galicia A, Lapasaran E. 1991. A contribution to the biology of Herengula tawilis in Lake Taal, Batangas. In: Quezon City, Philippines: Paper Presented during the 5th DA-BAR National Research Symposium. Department of Agriculture. p. 31.

Bensam P. 1987. A preliminary review of our knowlede on the early life histories of Clupeiformes from Indian waters with provisional keys for identifying eggs and early larvae. La Mer. 9: 158167.

Blaxter JHS. 1991. The effect of temperature on larval fishes. Netherlands Journal of Zoology. 42(2): 336-357

Bleher H. 1996. Bombon. Aqua Geographia 12: 6-34.

Castillo B, Castillo A, Gonzales C. 1975. Tawilis fishery resources investigation of Lake Taal. Los Baños, Laguna: Philippine Council for Agriculture and Resources Research Fisheries Forum. Philippine Council for Agriculture and Resources Research.

Castillo B, Gonzales C. 1976. Hydrology of Taal Lake. Fisheries Research Journal of the Philippines. 1: 62-75.

Catedral MMB. 2002. A preliminary study on some aspects of the reproductive biology of Sardinella tawilis (Herre, 1927) in Taal Lake, Batangas. BS Thesis. University of the Philippines Los Baños.

Cushing D. 1990. Plankton production and yearclass strength in fish populations: an update of the match/mismatch hypothesis. Advances in Marine Biology 26: 249-293.

DENR. 2011. Taal Volcano Protected Landscape Management Plan 2011-2020. Batangas, Philippines: Department of Environment and Natural Resources.

Ditty JG, Farooqi T, Shaw RF. 2006. Chapter 3 CLUPEIDAE: Sardines \& herrings. In: Early Stages Atlantic Fishes: An Identification Guide for the West Central North Atlantic. p. 73-100.

Ditty JG, Houde E, Shaw RF. 1994. Egg and larval 
development of Spanish Sardine Sardinella aurita, with a synopsis of characters to identify Clupeid larvae from the Northern Gulf of Mexico. Bulletin of Marine Science 54: 367-380.

Doyle MJ, Morse WW, Kendall AWJ. 1993. A comparison of larval fish assemblages in the temperate zone of the northeast Pacific and northwest Atlantic oceans. Bulletin of Marine Science 53: 588-644.

Ellis JR, Milligan SP, Readdy L, Taylor N, Brown MJ. 2012. Spawning and nursery grounds of selected fish species in UK waters. Science Series Technical Report 147: 56.

García-García LM, Ruiz-Villareal M, Bernal M. 2016. A biophysical model for simulating early life stages of sardine in the Iberian Atlantic stock. Fisheries Research 173: 250-272

Hargrove T. 1991. The mysteries of Taal. A Philippine volcano and lake, her sea life and lost towns. Manila: Bookmark.

Laprise R, Pepin P. 1995. Factors influencing the spatio-temporal occurrence of fish eggs and larvae in a northern physically dynamic coastal environment. Marine Ecology Progress Series 122: 73-92.

Lasker R. 1985. What Limits Clupeoid Production? Canadian Journal of Fisheries and Aquatic Sciences 42: 31-38

Leis JM, Carson-Ewart BM. 2000. The larvae of IndoPacific coastal fishes: An identification guide to marine fish larvae. Leiden, The Netherlands: Brill Publisher.

Magsino RM. 2016. Feeding biology and diet composition of the freshwater sardine, Sardinella tawilis from Taal Lake (Batangas) in Southern Luzon, Philippines. De La Salle Lipa Journal of Education, Arts and Sciences. 2: 1-12.

Mamaril Sr. A, Fernando C. 1978. Freshwater zooplankton of the Philippines (Rotifera, Cladocera and Copepoda). Natural and Applied Sciences Bulletin. University of the Philippines. 30: 109-221.
Moser HG. 1996. The early stages of fishes in the California current region. California Cooperative Oceanic Fisheries Investigations (CalCOFI) Atlas No. 33..

Morote E, Olivar MP, Villate F, Uriarte I. 2010. A comparison of anchovy (Engraulis encrasicolus) and sardine (Sardina pilchardus) larvae feeding in the northwest Mediterranean: influence of prey availability and ontogeny. ICES Journal of Marine Science 67(5): 897-908

Munuera-Fernandez I, Gonzales-Quiros R. 2006. Analysis of feeding of Sardina pilchardus (Walbaum, 1792) larval stages in the central Cantabrian Sea. Scientia Marina 70S1: 131-139

Mutia MTM. 2015. Environmental Influences on the reproductive biology and population dynamics of Sardinella tawilis in Lake Taal, Philippines. PhD Dissertation. University of the Philippines Los Baños.

Mutia MTM, Magistrado ML, Muyot MC. 2004. Status of Sardinella tawilis in Lake Taal, Batangas, Philippines. In: Proc 8th Zon Res Dev Rev. De La Salle University, Taft Avenue, Manila: Philippine Council for Aquatic and Marine R\&D and Southern Luzon Center for Aquatic and Marine R\&D.

Mutia MTM, Muyot MC, Torres F, Faminialagao C. 2010. Seasonality, abundance and biology of tawilis (Sardinella tawilis) in Lake Taal, Batangas. In: Proceedings of the 2nd National Congress on Philippine Lakes. SEARCA, UPLB.

Mutia MTM, Sarmiento KP, Muyot MC, Mendiola MJR, Tordecilla BD, Santos MD. 2017. Larvae Identification and Development of the only Freshwater Sardinella, Sardinella tawilis Endemic to Taal Lake, Philippines. The Philippine Journal of Science 146: 257-265.

Olivar M, Salat J, Palomera I. 2001. Comparative study of spatial distribution patterns of the early stages of anchovy and pilchard in the NW Mediterranean Sea. Marine Ecology Progress Series 217: 111-120.

Papa RDS, Pagulayan RC, Pagulayan AEJ. 2008. 
Zooplanktivory in the endemic freshwater sardine, Sardinella tawilis (Herre 1927) of Taal Lake, the Philippines. Zoological Studies 47: 535-543.

Papa RDS, Zafaralla MT. 2011. The composition, diversity and community dynamics of limnetic zooplankton in a tropical caldera lake (Lake Taal, Philippines). Raffles Bulletin of Zoology 59: 2-7.

Perez T, Enriquez EE, Guerrero RDI, Simon D, Schiemer F. 2008. Catchment Characteristics, Hydrology, Limnology and Socio-Economic Features of Lake. In: Schiemer F, Simon D, Amarasinghe US, Moreau J, editors. Aquatic Ecosystem Development: Comparative Asian Perspectives. Biology of inland water series. Leiden, The Netherlands: Backhuys Publishers. p. 63-80.

Richards WJ. 2005. Early Stages of Atlantic Fishes: An Identification Guide for the Western Central North Atlantic, Two Volume Set. CRC Press.

Sabates A. 2004. Diel vertical distribution of fish larvae during the winter-mixing period in the Northwestern Mediterranean. ICES Journal of Marine Science 61(8): 1243-1252.

Sabates A, Sabatés A. 1990. Distribution pattern of larval fish populations in the northwestern Mediterranean. Marine Ecology Progress Series 59: 75-82.

Santos AMP, dos Santos RP, Peliz A. 2006. Vertical distribution of the European sardine (Sardina pilchardus) larvae and its implications for their survival. Journal of Plankton Research 28(5): 523-532.

Sarpedonti V, Anunciação ÉMS da, Bordalo AO. 2013. Spatio-temporal distribution of fish larvae in relation to ontogeny and water quality in the oligohaline zone of a North Brazilian estuary. Biota Neotropica 13: 55-63.
Silva L, Faria AM, Teodósio MA, Garrido S. 2014. Ontogeny of swimming behaviour in sardine Sardina pilchardus larvae and effect of larval nutritional condition on critical speed. Marine Ecology Progress Series 504: 287-300

Smith PE, Richardson SL. 1977. Standard techniques for pelagic fish egg and larva surveys. FAO Fisheries Technical Paper No. 175.

Somarakis S, Ganias K, Siapatis A, Koutsikopoulos C, MacHias A, Papaconstantinou C. 2006. Spawning habitat and daily egg production of sardine (Sardina pilchardus) in the eastern Mediterranean. Fish Oceanography 15: 281-292.

Villanueva LS, Luistro AP, Calabig CS. 1995. Assessment of Taal Lake Capture Fisheries with Emphasis on the Exploitation of Herengula tawilis. Tanauan, Batangas.

Voss R, Dickmann M, Schmidt J. 2009. Feeding ecology of sprat (Sprattus sprattus L.) and sardine (Sardina pilchardus W.) larvae in the German bight, north sea. Oceanologia 51 (1): 119-140

Watson W, Sandknop EM. 1996. Clupeidae: Herrings. In: Moser HG, editor. Early stages of fishes in the California Current Region. Calcofi Atlas. p. 159-172.

Whitehead P. 1985. FAO species catalogue. Vol. 7. Clupeoid fishes of the world. An annotated and illustrated catalogue of the herrings, sardines, pilchards, sprats, shads, anchovies and wolfherrings. Part 1 - Chirocentridae, Clupeidae and Pristigasteridae. FAO Fisheries Synopsis. 125: $1-303$.

Wongratana T. 1980. Systematics of clupeoid fishes of the Indo-Pacific region. PhD Thesis. University of London.

Zafaralla MT. 1998. Microalgae of Taal Lake. Bicutan, Taguig, Metro Manila: NAST. 